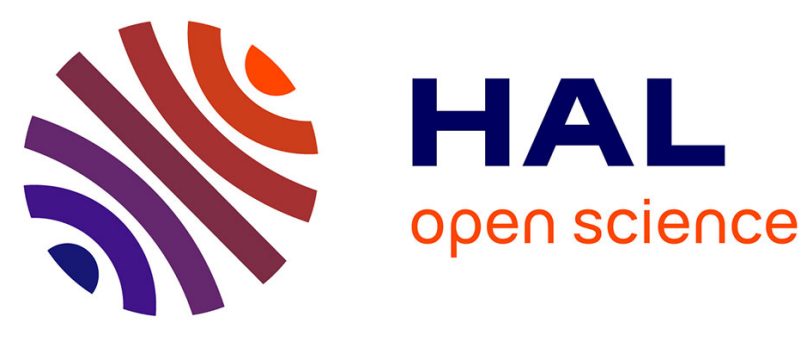

\title{
E-cadherin mediates the aggregation of breast cancer cells induced by tamoxifen and epidermal growth factor
}

Loredana Mauro, Michele Pellegrino, Rosamaria Lappano, Adele Vivacqua, Francesca Giordano, Maria Grazia Palma, Sebastiano Andò, Marcello

Maggiolini

\section{To cite this version:}

Loredana Mauro, Michele Pellegrino, Rosamaria Lappano, Adele Vivacqua, Francesca Giordano, et al.. E-cadherin mediates the aggregation of breast cancer cells induced by tamoxifen and epidermal growth factor. Breast Cancer Research and Treatment, 2009, 121 (1), pp.79-89. 10.1007/s10549-009-0456-4 . hal-00485062

\section{HAL Id: hal-00485062 \\ https://hal.science/hal-00485062}

Submitted on 20 May 2010

HAL is a multi-disciplinary open access archive for the deposit and dissemination of scientific research documents, whether they are published or not. The documents may come from teaching and research institutions in France or abroad, or from public or private research centers.
L'archive ouverte pluridisciplinaire HAL, est destinée au dépôt et à la diffusion de documents scientifiques de niveau recherche, publiés ou non, émanant des établissements d'enseignement et de recherche français ou étrangers, des laboratoires publics ou privés. 


\title{
E-cadherin mediates the aggregation of breast cancer cells induced by tamoxifen and epidermal growth factor
}

\author{
Loredana Mauro $^{1, \S}$, Michele Pellegrino ${ }^{1, \S}$, Rosamaria Lappano ${ }^{2}$, Adele Vivacqua ${ }^{2}$, \\ Francesca Giordano ${ }^{1}$, Maria Grazia Palma ${ }^{1}$, Sebastiano Andò $^{{ }^{*}}$, Marcello Maggiolini ${ }^{2}$ \\ ${ }^{1}$ Department Cellular Biology, ${ }^{2}$ Department Pharmaco-Biology, \\ University of Calabria, Cosenza - Italy
}

$\S$ Loredana Mauro and Michele Pellegrino contributed equally to this work

Running title: OHT and EGF induce E-cadherin expression

Key words: Tamoxifen, EGF, E-cadherin, Three-dimensional cultures, Breast cancer.

\section{*Corresponding Author:}

Prof. Sebastiano Andò

Department Cell Biology

University of Calabria

Arcavacata-Rende (CS) 87030, ITALY

Tel: +39/0984/496201, Fax: +39/0984/492929

E-mail: sebastiano.ando@unical.it 


\begin{abstract}
In the present study, we evaluated the ability of 4-hydroxytamoxifen (OHT) and epidermal growth factor (EGF) to regulate homotypic adhesion in MCF7 breast cancer cells. Our results demonstrate that OHT and EGF activate the E-cadherin promoter, increase E-cadherin mRNA and protein expression and enhance homotypic aggregation of MCF7 cells. Interestingly, an ER $\alpha$ and EGFR cross-talk is involved in the E-cadherin expression by OHT and EGF as demonstrated by knocking-down either receptor. On the basis of our findings, the well-established cross-talk between ER $\alpha$ and EGFR could be extended to the modulation of E-cadherin expression by OHT and EGF. Thus, the potential ability of tamoxifen to induce cell-cell aggregation may contribute to the biological response of pharmacological intervention in breast cancer patients.
\end{abstract}




\section{Introduction}

Breast cancer is the most common malignancy in women worldwide with over one million cases diagnosed each year [1-3]. Estrogen is required for normal proliferation and differentiation of breast epithelial cells and is implicated in the development and progression of breast cancer [4]. The classical mechanism of estrogen action mainly involves two members of the nuclear receptor superfamily, the estrogen receptor (ER) $\alpha$ and ERß [5]. Steroid receptors, including ER $\alpha$, have two main transcriptional activation functions named AF1 and AF2 which are associated with the N-terminal and the hormone binding domains, respectively. Agonists of ER $\alpha$ induce a conformational change in the hormone binding pocket that allows the recruitment of coactivators, which in turn maximize the transcriptional response to ligands [6]. Antagonists of ERs bind to the hormone binding pocket, however they block the AF2 in an inactive conformation. In addition, ER $\alpha$ can be activated by a host of extracellular signals, including growth factors, in the absence of the cognate ligand 17ß-estradiol $\left(\mathrm{E}_{2}\right)$ [7-9]. Of interest, partial antagonists of ER $\alpha$, such as 4-hydroxytamoxifen (OHT), may display cell- and promoter-specific agonist effects that are thought to be due, at least in part, to AF1 activity and/or to the ability to recruit cofactors [10-12]. OHT was the first antiestrogen approved for the clinical management of ER-positive breast cancers and has been recommended as first-line treatment for the past three decades [4]. Despite the beneficial effects of OHT for patients at all stages of ER-positive breast cancer [13], the major obstacle to its use is the development of tamoxifen-resistance which either occurs de novo or in patients showing initial benefits [14]. Growth factors, including EGF, are involved in breast cancer progression $[15,16]$. Binding of EGF to the cognate receptor EGFR initiates a transduction cascade with sequential phosphorylation and activation of a series of intracellular signaling molecules. Among the downstream pathways activated by EGF, it is important to mention the cell survival cascade mediated by PI3-kinase (PI3-K) and AKT/PKB [17,18], the cell proliferation pathway mediated by the mitogen activated protein kinases (MAPK) ERK1/2 [19,20] and the stress- 
induced pathways mediated by the stress activated protein kinase/JNK and p38 MAPKs [21]. On the other hand, rapid $\mathrm{E}_{2}$ stimulation through $\mathrm{ER} \alpha$ also activates these transduction pathways which synergistically trigger cell survival and proliferation [22,23]. In addition, ER $\alpha$ can be promptly activated in a ligand-independent manner by EGF which mimics $\mathrm{E}_{2}$ in inducing agonist effects including breast cancer cell growth [24-26].

In the epithelium and in epithelium-derived tumors, cell-cell adhesion and tumor mass mostly rely on functions of E-cadherin, which is an intercellular adhesion molecule generally considered as a tumor suppressor [27,28]. Alteration in the activity of E-cadherin and the cadherin-catenin complex has been implicated in cancer progression [29], invasion [30-32], and metastasis [33,34]. Considering that in our recent study ER $\alpha$-mediated homotypic tumor cell adhesion was induced by $E_{2}$ through an increase of E-cadherin expression [35], in the present investigation we evaluated whether the mixed ER agonist/antagonist OHT and the well-known ER $\alpha$ activator EGF could mimic the aforementioned action of $E_{2}$ in MCF7 breast cancer cells. 


\section{Materials and Methods}

Plasmids. The plasmid containing the human E-cadherin promoter (-p1008/+49) was obtained from Dr. Y. S. Chang (Chang-Gung University, Republic of China) [36].

Cell lines and culture conditions. MCF7 cells were grown in DMEM/F-12 containing 10\% FBS supplemented with $1 \%$ L-glutamine and 1\% penicillin/streptomycin (Sigma, Milan, Italy). Cells were switched to medium without serum $48 \mathrm{~h}$ before RT-PCR, immunoblots, and evaluation of ERK1/2 phosphorylation.

Transfections and Luciferase Assays. MCF7 cells were plated into 24-well dishes with 500 $\mu 1$ regular growth medium/well the day before transfection. The medium was replaced with that lacking serum on the day of transfection, which was performed using FuGene6 reagent as recommended by the manufacturer (Roche Diagnostics, Milan, Italy) with a mixture containing $0.5 \mu \mathrm{g}$ reporter plasmid and 2ng pRL-thymidine kinase. After 24h, we renewed the serum-free medium containing the indicated treatment, and then cells were incubated for approximately $16 \mathrm{~h}$. Luciferase activity was measured with the dual luciferase kit (Promega Italia, Milan, Italy) according to the manufacturer's recommendations. Firefly luciferase values were normalized to the internal transfection control provided by the Renilla luciferase activity. The data are reported as normalized relative light unit (RLU) values.

RT-PCR. The evaluation of gene expression was performed by semiquantitative RT-PCR as we have previously described [37]. For E-cadherin, pS2 and the acidic ribosomal phosphoprotein P0 (36B4), which was used as a control gene, the primers were, respectively, 5'-GGAATCCAAGCAGAATTGC3' (E-cadherin forward), and 5'-TATGTGGCAATGCGTTCTCTATCCA-3' (E-cadherin reverse), 5'- 
TTCTATCCTAATACCATCGACG-3' (pS2 forward) and 5'-TTTGAGTAGTCAAAGTCAGAGC-3' (pS2 reverse), 5'-CTCAACATCTCCCCCTTCTC-3' (36B4 forward), and 5'-

CAAATCCCATATCCTCGTCC-3' (36B4 reverse), to yield products of 285, 210 and $408 \mathrm{bp}$, respectively, with 20,15 and 15 PCR cycles.

Western Blotting. Equal amounts of whole protein extract were resolved on a 8-10\% SDSpolyacrylamide gel, transferred to a nitrocellulose membrane (GE Healthcare, Milan, Italy), probed overnight at $4^{\circ} \mathrm{C}$ with the antibodies against E-cadherin, EGFR, B-actin (Santa Cruz Biotechnology, Milan, Italy), pERK1/2 and total ERK (Cell Signaling Technology and Celbio, Milan, Italy) and then revealed using the enhanced chemiluminescence system (GE Healthcare).

ERo, EGFR and Sp1 silencing experiments. Cells were plated onto 10-cm dishes, maintained in antibiotic-free medium for $24 \mathrm{~h}$ and then transfected for additional $24 \mathrm{~h}$ before treatments with a mixture

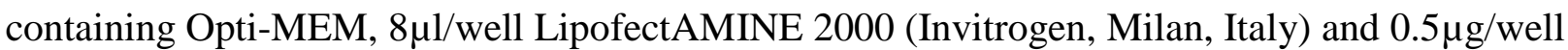
control siRNA or ER $\alpha$ siRNA (Sigma), vector or shEGFR purchased from SuperArray (Bioscience Corporation, Frederick, MD), 200nM/well of control siRNA or Sp1 siRNA (Applied Biosystems, Milan, Italy).

Chromatin immunoprecipitation (ChIP) assay. MCF7 cells were treated with $1 \mu \mathrm{M}$ OHT or $100 \mathrm{ng} / \mathrm{ml}$ EGF for $1 \mathrm{~h}$. Thereafter, cells were cross-linked with $1 \%$ formaldehyde and sonicated. Supernatants were immunocleared with salmon DNA/protein A agarose (Upstate Biotechnology, Lake Placid, NY) and immunoprecipitated with anti-ER $\alpha$ antibody or with anti-RNA Pol II (Santa Cruz Biotechnology). Pellets were washed as reported [38], eluted with elution buffer and digested with proteinase K. DNA was obtained by phenol/chloroform extraction and precipitated with ethanol; $3 \mu$ l of 
each sample were used for PCR with Sp1 primers: 5'-TAGCAACTCCAGGCTAGAGG-3' and 5'AACTGACTTCCGCAAGCTCACA-3'. The PCR conditions were $94^{\circ} \mathrm{C}$ for $1 \mathrm{~min}, 56^{\circ} \mathrm{C}$ for $2 \mathrm{~min}$, and $72^{\circ} \mathrm{C}$ for $2 \mathrm{~min}$. The amplification products obtained in 30 cycles were analysed in a $2 \%$ agarose gel and visualized by ethidium bromide staining.

Three-dimensional spheroid cultures. MCF7 cells were plated in single-cell suspension in 2\%-agarcoated plates and left untreated or treated with $1 \mu \mathrm{M}$ OHT or $100 \mathrm{ng} / \mathrm{ml}$ EGF for $48 \mathrm{~h}$. To block Ecadherin function, the medium was supplemented with E-cadherin antibody (1:100 dilution; Chemicon International, Temecula, CA) or EGTA to a final concentration of 4mM. To generate three-dimensional spheroids, the plates were rotated for $4 \mathrm{~h}$ at $37^{\circ} \mathrm{C}$. The three-dimensional cultures were photographed using a phase-contrast microscope (Olympus, Sun Valley, CA). The extent of aggregation was scored by measuring the spheroids with an ocular micrometer. The spheroids between 25 and 50, 50 and 100, and $>100 \mu \mathrm{m}$ (in the smallest cross-section) were counted in 10 different fields under $\times 10$ magnification.

Statistical Analysis. Statistical analysis was performed using ANOVA, followed by Newman-Keuls testing to determine differences in means. 


\section{Results}

\section{OHT and EGF transactivate the E-cadherin promoter and induce E-cadherin mRNA and protein}

expression.

On the basis of our previous study demonstrating that E-cadherin expression is induced by $\mathrm{E}_{2}$ [35], and considering the potential of OHT and EGF to exert agonist activity through ER $\alpha$, we evaluated whether these compounds could regulate E-cadherin expression like $\mathrm{E}_{2}$. An expression vector containing the human E-cadherin promoter was transactivated by OHT and EGF in MCF7 cells (Fig. 1A). treating cells with OHT in combination with EGF the transcriptional response was similar using each compound alone (Fig. 1A). In line with these findings, OHT and EGF induced E-cadherin mRNA expression at the same extent treating cells with both compounds (Fig. 1B, C). Then, we explored whether the agonistic effect displayed by OHT in upregulating E-cadherin expression was also evident in the modulation of the classical estrogen target gene pS2. Hence, MCF7 cells were treated with $\mathrm{E}_{2}$, OHT, the combination of both compounds and EGF. The up-regulation of pS2 by $\mathrm{E}_{2}$ was abolished by OHT (Fig. 2A, B), confirming that OHT can act as a mixed agonist-antagonist depending on the gene response evaluated. Moreover, also EGF was able to upregulate pS2 mRNA expression (Fig.2A,B). Thereafter, we asked whether OHT and EGF could up-regulate E-cadherin expression at the protein level. Upon exposure to each compound or a combination of both, we observed an increase of Ecadherin protein levels which was prevented by the ER antagonist ICI, the Src and ERK inhibitors PP2 and PD, respectively (Fig. 3A-D). The latter findings showing the involvement of the MAPK pathway was also confirmed by the ability of OHT and EGF to trigger a rapid ERK1/2 phosphorylation similar to that observed upon $\mathrm{E}_{2}$ exposure (Fig. 4). Taken together these results suggest that both OHT and EGF involve ER $\alpha$ as well as Src and MAPK signaling in the regulation of E-cadherin expression. 


\section{ER $\alpha$ and EGFR silencing abrogates the E-cadherin up-regulation by OHT and EGF.}

The results obtained prompted us to define the role exerted by ER $\alpha$ and EGFR in mediating E-cadherin stimulation by both OHT and EGF. Interestingly, after knocking-down ER $\alpha$ expression neither OHT nor EGF was able to up-regulate E-cadherin expression (Fig. 5A, B) confirming the data obtained using the ER antagonist ICI. Moreover, EGFR silencing also resulted in the abrogation of the E-cadherin increase upon exposure to each compound (Fig. 5C, D). The role of EGFR signaling was further ascertained observing an upregulation of EGFR protein expression particularly treating MCF7 cells with OHT (Fig. 5E). These results suggest that a functional cross-talk between ER $\alpha$ and EGFR triggers E-cadherin expression by the agents used.

\section{OHT and EGF induce the recruitment of ERa to the Sp1 site located within the E-cadherin} promoter sequence.

The interaction of ER $\alpha$ with the E-cadherin promoter sequence was investigated by ChIP assay. To this end, the MCF7 chromatin was immunoprecipitated with anti-ER $\alpha$ or anti-RNA-Pol II antibodies. PCR was used to determine the recruitment of ER $\alpha$ to the E-cadherin region containing the Sp1 site (-144/132nt). Interestingly, the weak ER $\alpha$ recruitment to the E-cadherin promoter observed in cells treated with vehicle increased upon OHT and EGF treatment (Fig. 6A). In addition, both compounds induced the recruitment of RNA-Pol II indicating the ability to stimulate E-cadherin transcription (Fig. 6A). Next, the E-cadherin protein increase stimulated by OHT and EGF was no longer evident silencing Sp1 in MCF7 cells (Fig. 6B). A similar result was obtained using mithramycin, an inhibitor of Sp1-DNA interactions (Fig. 6C).These data confirm the role exerted by the Sp1 site in mediating the upregulation of E-cadherin upon OHT and EGF treatments. 


\section{OHT and EGF induce MCF7 cell-cell adhesion in three-dimensional cultures.}

On the basis of our previous study showing that the increase of E-cadherin expression by $E_{2}$ is responsible for enhanced MCF7 cell aggregation [35], we evaluated whether OHT and EGF could induce the same effect. Considering that multicellular spheroid cultures can closely reproduce some biological features of tumors and improve the relevance of results obtained by in vitro studies [39-41], we used three-dimensional MCF7 cultures as an experimental model. MCF7 cell-cell adhesion was enhanced following a 48h exposure to OHT and EGF (Fig. 7), which both induced the formation of spheroids prevalently with a diameter greater than $50 \mu \mathrm{m}$ (Table 1). Moreover, supplementing the culture medium with function-blocking E-cadherin antibody or the calcium-chelating agent EGTA we verified the direct involvement of E-cadherin in the enhanced cell-cell adhesion upon OHT and EGF treatments. In the presence of the E-cadherin antibody, the MCF7 cells showed the formation of small aggregates and limited intercellular contact, whereas in the presence of EGTA MCF7 cells remained rounded and separately suspended (Fig. 7). 


\section{Discussion}

Estrogens play a major role in the development of breast cancer. Nearly $70 \%$ of breast tumors express the ER $\alpha$ which allows for the use of antiestrogen therapy as a reliable therapeutic approach for all stages of the disease [42]. The ER antagonist tamoxifen has been shown to improve survival in early breast cancer [43] as well as the quality of life in patients with metastatic disease [13]. Despite the documented benefits of ER-targeted therapy in breast cancer, approximately 50\% of patients with advanced disease do not respond to first-line treatment with tamoxifen due to de novo or intrinsic resistance. Furthermore, almost all patients with metastatic disease and many who receive tamoxifen as adjuvant therapy eventually experience tumor relapse (acquired resistance). Thus, tamoxifen resistance occurs frequently in breast cancer patients and seriously limits treatment efficacy $[42,44]$. Multiple mechanisms have been proposed to contribute to the failure of tamoxifen therapy, including changes in the uptake or metabolism of tamoxifen, presence of ER mutants and ligand-independent ER activation, loss of expression of ER and/or cofactors and modification of the estrogen response element $[42,45]$. A large body of clinical and experimental studies has suggested that alteration of ER function by growth factor pathways may be involved in tamoxifen resistance [14, 42,46-48]. In this context, it has been reported that phosphorylation of ER $\alpha$ by EGFR-mediated signaling enhances the estrogeninduced transcriptional activity [49,50]. An increased recruitment of coactivators, such as AIB1 [51], and conformational changes [52] after receptor phosphorylation also contribute to enhanced transcriptional activity of ER $\alpha$ in tamoxifen-resistant breast cancer cells. In addition, an inverse relationship between the expression of ER $\alpha$ and EGFR or c-erbB2 was observed in primary breast cancer samples and was associated with decreased sensitivity to endocrine therapy and a poorer prognosis [47,53]. Hormone-dependent breast cancer cells engineered to overexpress EGFR and cerbB2 resulted in stimulated hormone-independent cell growth [54,55]. 
Our present data demonstrate that EGF enhances E-cadherin expression and promotes homotypic aggregation of breast cancer cells maintained as three-dimensional cultures.

E-cadherin is an intercellular adhesion molecule generally implicated as tumor suppressor in several types of epithelial tumors, based on findings that the expression of this homotypic adhesion molecule is frequently lost in human epithelial cancers [29-31]. However, it has well been shown in ovarian epithelial tumors that E-cadherin expression is much more elevated than normal ovaries, suggesting that E-cadherin can play a role in the development of ovarian carcinomas [56]. For instance, it is worth to mention that E-cadherin may serve not only as an intercellular adhesion molecule, but it may also trigger intracellular activation of proliferation and survival signals $[57,35]$. Our recent findings provided evidence that $\mathrm{E}_{2}$ may be involved in mammary tumorigenesis on the basis of its stimulatory effects on primary tumor mass either in vivo using MCF7 cell tumor xenograft or in vitro using MCF7 three-dimensional cultures [35]. These actions were elicited by $\mathrm{E}_{2}$ through homotypic tumor cell adhesion consequent to an increase of E-cadherin expression [35].

A number of studies have evaluated the usefulness of E-cadherin expression with respect to survival of breast cancer patients. Several studies indicate that reduced E-cadherin expression is an independent indicator of poor survival, particularly in node-negative patients [58-61]. However, other studies have found E-cadherin to be of little use in predicting clinical behavior of breast cancer patients [62]. Indeed, one study even noted that strong E-cadherin immunostaining correlated with poor survival [63]. In short, there currently are conflicting opinions about the prognostic value of altered E-cadherin expression. Thus, the usefulness of E-cadherin as a predictor of clinical behavior for breast cancer patients is still under debate.

In the present study, we showed that a cross-talk between ER $\alpha$ and EGFR was involved in E-cadherin expression by both OHT and EGF as demonstrated using the pure ER antagonist ICI, the Src and ERK inhibitors PP2 and PD, respectively, and most importantly silencing either ER $\alpha$ or EGFR expression. 
Moreover, OHT and EGF stimulated ER $\alpha$ recruitment to the $\mathrm{Sp} 1$ site within the E-cadherin promoter region, whereas blocking this site, either by silencing $\mathrm{Sp} 1$ or using mithramycin, $\mathrm{ER} \alpha$ binding to the Ecadherin promoter region was no longer evident.

Thus, in conclusion in this study, we provide further insights into the molecular mechanisms involved in the agonist activity exerted by tamoxifen in breast cancer, through the evidence that OHT per se is able to activate the promoter of E-cadherin, increasing E-cadherin expression at the mRNA and protein levels and thus may enhance homotypic aggregation of MCF7 breast cancer cells.

In addition, we have demonstrated that E-cadherin is a target of a cross-talk between EGF and OHT/ER signaling, since the upregulatory effect induced by OHT on E-cadherin expression was abrogated in the presence of either ER $\alpha$ or EGFR silencing. It is worth to note that in our experimental conditions tamoxifen induced an enhanced expression of EGFR protein levels, which may contribute to the failure of adjuvant endocrine therapy in breast cancer, as suggested by a growing body of data. The latter observations highlights how the agonistic effect of tamoxifen and EGF may sustains tumor mass growth through cell-cell aggregation. 


\section{Acknowledgments}

This work was supported by MURST, Ex 60\%, AIRC grants 2007, 2008, MFAG 2008. 


\section{References}

1. Smigal C, Jemal A, Ward E et al (2006) Trends in breast cancer by race and ethnicity: update 2006.

CA Cancer J Clin 56(3):168-183

2. Bray F, McCarron P, Parkin DM (2004) The changing global patterns of female breast cancer incidence and mortality. Breast Cancer Res 6:229-239

3. Jemal A, Thomas A, Murray T et al (2002) Cancer statistics, 2002. CA Cancer J Clin 52:23-47

4. Ishii Y, Waxman S, Germain D (2008) Tamoxifen stimulates the growth of cyclin D1overexpressing breast cancer cells by promoting the activation of signal transducer and activator of transcription 3. Cancer Res 68(3):852-860

5. Giguere V, Tremblay A, Tremblay GB (1998) Estrogen receptor beta: re-evaluation of estrogen and antiestrogen signaling. Steroids 63(5-6):335-339

6. Mc Kenna NJ, O' Malley BW (2002) Combinatorial control of gene expression by nuclear receptors and coregulators. Cell 108:465-474

7. Cenni B, Picard D (1999) Ligand-independent activation of steroid receptors: new roles for old players. Trends Endocrinol Metab 10: 41-46 
8. Weigel NL, Zhang Y (1998) Ligand-independent activation of steroid hormone receptors. J Mol Med 76, 469-479

9. Bunone G, Briand PA, Miksicek RJ et al (1996) Activation of the unliganded estrogen receptor by EGF involves the MAP kinase pathway and direct phosphorylation. EMBO J 15(9):2174-2183

10. Feng W, Webb P, Nguyen $\mathrm{P}$ et al (2001) Potentiation of estrogen receptor activation function 1 (AF-1) by Src/JNK through a serine 118-independent pathway. Mol Endocrinol 15: 32-45

11. Lavinsky RM, Jepsen K, Heinzel T et al (1998) Diverse signaling pathways modulate nuclear receptor recruitment of N-CoR and SMRT complexes. PNAS 95: 2920-2925

12. Lee H, Jiang F, Wang Q et al (2000) MEKK1 activation of human estrogen receptor alpha and stimulation of the agonistic activity of 4-hydroxytamoxifen in endometrial and ovarian cancer cells. Mol Endocrinol 14:1882-1896

13. Jaiyesimi IA, Buzdar AU, Decker DA et al (1995) Use of tamoxifen for breast cancer: twentyeight years later. J Clin Oncol 13:513-529

14. Massarweh S, Osborne CK, Creighton CJ et al (2008) Tamoxifen resistance in breast tumors is driven by growth factor receptor signaling with repression of classic estrogen receptor genomic function. Cancer Res 68(3):826-833 
15. Lichtner RB (2003) Estrogen/EGF receptor interactions in breast cancer: rationale for new therapeutic combination strategies. Biomed Pharmacother 57(10):447-451

16. Kim H, Muller WJ (1999) The role of the epidermal growth factor receptor family in mammary tumorigenesis and metastasis. Exp Cell Res 253(1):78-87

17. Vanhaesebroeck B, Alessi DR (2000) PI3K-PDK1 connection: more than just a road to PKB. Biochem J 346:561-576

18. Cantley LC (2002) The phosphoinositide 3-kinase pathway. Science 296:1655-1657

19. Pearson G, Robinson F, Beers Gibson T et al (2001) Mitogen-activated protein (MAP)kinase pathways: regulation and physiological functions. Endocr Rev 22:153-183

20. Peyssonnaux C, Eychene A (2001) The Raf/MEK/ERK pathway: new concepts of activation. Biol Cell 93: 53-62

21. Kyriakis JM, Avruch J (2001) Mammalian mitogen-activated protein kinase signal transduction pathways activated by stress and inflammation. Physiol Rev 81:807-869

22. Schiff R, Massarweh S, Shou J et al (2003) Breast cancer endocrine resistance: how growth factor signaling and estrogen receptor coregulators modulate response. Clin Cancer Res 9: 447S454S 
23. Santen RJ, Song RX, McPherson R et al (2002) The role of mitogen-activated protein (MAP)kinase in breast cancer. J Steroid Biochem Mol Biol 80:239-256

24. Vignon F, Bouton MM, Rochefort H (1987) Antiestrogens inhibit the mitogenic effect of growth factors on breast cancer cells in the total absence of estrogens. Biochem Biophys Res Commun $146: 1502-1508$

25. Ignar-Trowbridge DM, Nelson KG, Bidwell MC et al (1992) Coupling of dual signaling pathways: epidermal growth factor action involves the estrogen receptor. Proc Natl Acad Sci U S A 89:4658-4662

26. Hewitt S, Harrell JC, Korach KS (2005) Lessons in estrogen biology from knockout and transgenic animals. Annu Rev Physiol 67:285-308

27. Takeichi M (1991) Cadherin cell adhesion receptors as a morphogenetic regulator. Science 251:1451-5

28. Takeichi M (1995) Morphogenetic roles of classic cadherins. Curr Opin Cell Biol 7:619-627

29. Perl AK, Wilgenbus P, Dahl U et al (1998) A causal role for E-cadherin in the transition from adenoma to carcinoma. Nature 392:190-193

30. Behrens J, Mareel MM, Van Roy FM et al (1989) Dissecting tumor cell invasion: epithelial cells acquire invasive properties after the loss of uvomorulin mediated cell-cell adhesion. J Cell Biol $108: 2435-2447$ 
31. Frixen UH, Behrens J, Sachs M et al (1991) E-cadherin mediated cell-cell adhesion prevents invasiveness of human carcinoma cells. J Cell Biol 113:173-185

32. Vleminckx K, Vakaet L Jr., Mareel M et al (1991) Genetic manipulation of E-cadherin expression by epithelial tumor cells reveals an invasion suppressor role. Cell 66:107-119

33. Dorudi S, Sheffield JP, Poulsom R et al (1993) E-cadherin expression in colorectal cancer. An immunocytochemical and in situ hybridization study. Am J Pathol 142:981-986

34. Mbalaviele D, Dunstan CR, Sasaki A et al (1996) E-cadherin expression in human breast cancer cells suppresses the development of osteolytic bone metastases in an experimental metastasis model. Cancer Res 56:4063-4070

35. Mauro L, Catalano S, Bossi G et al (2007) Evidences that leptin upregulates E-cadherin expression in breast cancer: effects on tumor growth and progression. Cancer Res 67(7):3412-3421.

36. Tsai CN, Tsai CL, Tse KP et al (2002) The Epstein-Barr virus oncogene product, latent membrane protein 1, induces the downregulation of E-cadherin gene expression via activation of DNA methyltransferases. Proc Natl Acad Sci U S A 99:10084-10089

37. Maggiolini M, Donze` O, Picard D (1999) A non-radioactive method for inexpensive quantitative RT-PCR. J Biol Chem 380:695-697 
38. Morelli C, Garofalo C, Sisci D et al (2004) Nuclear insulin receptor substrate 1 interacts with estrogen receptor a at ERE promoters. Oncogene 23:7517-7526

39. Dangles V, Femenia F, Laine V et al (1997) Two- and threedimensional cell structures govern epidermal growth factor survival function in human bladder carcinoma cell lines. Cancer Res 57:33603364

40. Kunz-Schughart LA, Kreutz M, Knuechel R (1998) Multicellular spheroids: a three-dimensional in vitro culture system to study tumour biology. Int J Exp Pathol 79:1-23

41. Santini MT, Rainaldi G (1999) Three-dimensional spheroid model in tumor biology. Pathobiology 67:148-157

42. Massarweh S, Schiff R (2006) Resistance to endocrine therapy in breast cancer: exploiting estrogen receptor/growth factor signaling crosstalk. Endocr Relat Cancer13(1):S15-24

43. Early Breast Cancer Trialists' Collaborative Group (EBCTCG) (1998) Tamoxifen for early breast cancer: an overview of the randomised trials. Lancet 351:1451-1467

44. Arpino G, Wiechmann L, Osborne CK et al (2008) Cross-talk between the estrogen receptor and the HER tyrosine kinase receptor family: molecular mechanism and clinical implications for endocrine therapy resistance. Endocrine Rev 29: 217-233 
45. Herynk MH, Fuqua SAW (2004) Estrogen receptor mutations in human disease. Endocrine Rev 25(6):869-898

46. Long B, McKibben BM, Lynch M et al (1992) Changes in epidermal growth factor receptor expression and response to ligand associated with acquired tamoxifen resistance or oestrogen independence in the ZR-75-1 human breast cancer cell line. Br J Cancer 65(6):865-869

47. Nicholson RI, McClelland RA, Gee JM et al (1994) Epidermal growth factor receptor expression in breast cancer: association with response to endocrine therapy. Breast Cancer Res Treat 29:117-125

48. Osborne CK, Shou J, Massarweh S et al (2005) Crosstalk between estrogen receptor and growth factor receptor pathways as a cause for endocrine therapy resistance in breast cancer. Clin Cancer Res $11(865 s): 865 s-870 s$

49. Joel P, Smith J, Sturgill T et al (1998) pp90rsk1 regulates estrogen receptor-mediated transcription through phosphorylation of Ser-167. Mol Cell Biol 18:1978-1984

50. Gee JM, Robertson JF, Gutteridge E et al (2005) Epidermal growth factor receptor/HER2/insulinlike growth factor receptor signalling and oestrogen receptor activity in clinical breast cancer. Endocr Relat Cancer 12: S99-111

51. Shou J, Massarweh S, Osborne CK et al (2004) Mechanisms of tamoxifen resistance: increased estrogen receptor-HER2/neu cross-talk in ER/HER2-positive breast cancer. J Natl Cancer Inst 96:926935 
52. Michalides R, Griekspoor A, Balkenende A et al (2004) Tamoxifen resistance by a conformational arrest of the estrogen receptor a after PKA activation in breast cancer. Cancer Cell Int 5:597-605

53. Nicholson RI, McClelland RA, Finlay P et al (1993) Relationship between EGF-R, c-erbB2 protein expression and Ki67immunostaining in breast cancer and hormone sensitivity. Eur J Cancer 29A:10181023

54. van Agthoven TT, van Agthoven TL, Portengen H et al (1992) Ectopic expression of epidermal growth factor receptors induces hormone independence in ZR-75-1 human breast cancer cells. Cancer Res 52:5082-5088.

55. Benz CC, Scott GK, Sarup JC et al (2000) Estrogen-dependent, tamoxifen-resistant tumorigenic growth of MCF-7cells transfected with HER2/neu. Breast Cancer Res Treat 24:85-95

56. Reddy P, Lui L, Ren C, et al (2005) Formation of E-cadherinmediated cell-cell adhesion activates AKT and mitogen activated protein kinase via phosphatidylinositol 3 kinase and ligand-independent activation of epidermal growth factor receptor in ovarian cancer cells. Mol Endocrinol 19:2564-78

57. Steinberg MS, McNutt PM (1999) Cadherins and their connections: adhesion junctions have broader functions. Curr Opin Cell Biol 11:554-60

58. Siitonen SM, Kononen JT, Helin HJ et al (1996). Reduced E-cadherin expression is associated with invasiveness and unfavorable prognosis in breast cancer. Am J Clin Pathol 105:394-402 
59. Charpin C, Garcia S, Bonnier P et al (1998) Reduced Ecadherin immunohistochemical expression in node-negative breast carcinomas correlates with 10-year survival. Am J Clin Pathol 109:431-438

60. Heimann R, Lan F, McBride R et al (2000). Separating favorable from unfavorable prognostic markers in breast cancer: The role of E-cadherin. Cancer Res 60:298-304

61. Asgeirsson KS, Jonasson JG, Tryggvadottir L et al (2000). Altered expression of E-cadherin in breast cancer: Patterns, mechanisms and clinical significance. Eur J Cancer 36:1098-1106

62. Lipponen P, Saarelainen E, Aaltomaa S et al (1994). Expression of E-cadherin (E-CD) as related to other prognostic factors and survival in breast cancer. J Pathol 174:101-109

63. Tan DS, Potts HW, Leong AC et al (1999). The biological and prognostic significance of cell polarity and E-cadherin in grade I infiltrating ductal carcinoma of the breast. J Pathol 189:20-2 


\section{Legend for figures}

Figure 1. OHT and EGF transactivate the E-cadherin promoter and increase E-cadherin mRNA expression.

A. MCF7 cells were transiently transfected with a luciferase reporter plasmid containing the full-length human E-cadherin promoter p-1008/+49 and treated with $1 \mu \mathrm{M}$ OHT, 100ng/ml EGF or a combination of both compounds. The luciferase activities were normalized to the internal transfection control. Each data point represents the mean \pm S.D. of three independent experiments performed in triplicate. B. The expression of E-cadherin was evaluated by semiquantitative RT-PCR in MCF7 cells treated with $1 \mu \mathrm{M}$ OHT, 100ng/ml EGF or a combination of both compounds for 16h; 36B4 levels were determined as a control. C. The quantitative representation of data (mean \pm S.D.) of three independent experiments. * indicates $\mathrm{p}<0.05$ for cells receiving vehicle (-) versus treatments.

Figure 2. OHT acts as an agonist for E-cadherin mRNA expression but as an antagonist for pS2 mRNA expression.

A. The expression of E-cadherin and pS2 was evaluated by semiquantitative RT-PCR in MCF7 cells treated with $1 \mu \mathrm{M}$ OHT, $100 \mathrm{nM} \mathrm{E}_{2}$, a combination of both compounds and 100ng/ml EGF for $16 \mathrm{~h}$; 36B4 levels were determined as a control. B. The quantitative representation of data (mean \pm S.D.) of three independent experiments. $*$ indicates $p<0.05$ for cells receiving vehicle (-) versus treatments.

\section{Figure 3. Immunoblots of E-cadherin from MCF7 cells.}

MCF7 cells were exposed for $16 \mathrm{~h}$ to $1 \mu \mathrm{M}$ OHT, 100ng/ml EGF or a combination of both compounds (A). MCF7 cells were exposed for $16 \mathrm{~h}$ to $1 \mu \mathrm{M}$ OHT and $100 \mathrm{ng} / \mathrm{ml} \mathrm{EGF}$ alone or in combination with $10 \mu \mathrm{M}$ ICI 182,780 (B), Src family tyrosine kinase inhibitor PP2 (C), MEK inhibitor PD 98059 (D). 
$ß$-actin serves as loading control. The quantitative representation of data (mean \pm S.D.) of three independent experiments after densitometry. * indicates $\mathrm{p}<0.05$ for cells receiving vehicle (-) versus treatments.

\section{Figure 4. ERK1/2 phosphorylation in MCF7 cells.}

MCF7 cells were treated for 10 min with $100 \mathrm{nM} \mathrm{E}_{2}, 1 \mu \mathrm{M}$ OHT or $100 \mathrm{ng} / \mathrm{ml}$ EGF. Total ERK proteins were used to normalize ERK1/2 expression. The quantitative representation of data (mean \pm S.D.) of three independent experiments after densitometry. * indicates $p<0.05$ for cells receiving vehicle (-) versus treatments.

Figure 5. ERa and EGFR silencing abrogates the up-regulation of E-cadherin by OHT and EGF. E-cadherin protein expression in MCF7 transfected with $0.5 \mu \mathrm{g} /$ well of ER $\alpha$ siRNA (A) or control siRNA $(\mathbf{B})$, shEGFR $(\mathbf{C})$ or vector $(\mathbf{D})$. After $24 \mathrm{~h}$ of transfection cells were treated with $1 \mu \mathrm{M}$ OHT or 100ng/ml EGF for 16h. EGFR protein expression in MCF7 treated for 16h with $1 \mu \mathrm{M}$ OHT or $100 \mathrm{ng} / \mathrm{ml}$ EGF (E). B-actin serves as loading control. This experiment was repeated three times with similar results. Most representative experiment is shown.

Figure 6. OHT and EGF induce the recruitment of ER $\alpha$ on the Sp1 site within E-cadherin promoter sequence.

A. MCF7 cells were treated for $1 \mathrm{~h}$ with $1 \mu \mathrm{M}$ OHT or $100 \mathrm{ng} / \mathrm{ml}$ EGF or left untreated then crosslinked with formaldehyde and lysed. The soluble chromatin was immunoprecipitated with the anti-ER $\alpha$ or the anti-RNA Pol II Abs. The E-cadherin promoter sequence containing Sp1 was detected by PCR with specific primers, as described in Materials and Methods. To determine input DNA, the E-cadherin promoter was amplified from $5 \mu 1$ of initial preparations of soluble chromatin (before 
immunoprecipitations). N, negative control provided by PCR amplification without DNA sample. This experiment was repeated three times with similar results. Most representative experiment is shown. Ecadherin protein expression evaluated by immunoblot in MCF7 cells treated for approximately $16 \mathrm{~h}$ and exposed to $1 \mu \mathrm{M}$ OHT or 100ng/ml EGF after knocking-down Sp1 (B) or preincubation with $200 \mathrm{nM}$ mithramycin (C). B-actin serves as loading control. The side panels show the quantitative representation of data (mean \pm S.D.) of three independent experiments including that of $\mathbf{A}, \mathbf{B}$ and $\mathbf{C}$. $*$ and $\bullet$ indicate $\mathrm{p}<0.05$ for cells received vehicle $(-)$ versus treatments.

\section{Figure 7. OHT and EGF induce cell-cell adhesion in three-dimensional cultures.}

E-cadherin-positive MCF7 cells were seeded in 2\% agar-coated plates and cultured as three dimensional spheroids. To block E-cadherin function, the medium was supplemented with E-cadherin antibody (1:100 dilution; a-E-cad) or EGTA (4 mM). Cells were untreated or treated with 1 $\mu \mathrm{M}$ OHT or 100ng/ml EGF for 48h and then photographed under phase-contrast microscopy. Bar, $50 \mu \mathrm{m}$.

\section{Table 1. Effect of OHT and EGF on cell aggregation in MCF7 breast cancer cells.}

MCF7 cells were cultured as three-dimensional spheroids in medium without serum and treated as reported. The extent of aggregation was scored by measuring the spheroid diameters with an ocular micrometer. The values represent a sum of spheroids in 10 optical fields under x10 magnification. The results are mean mean \pm S.D. from at least three experiments. Representative three-dimensional cultures are shown in Fig. 7. 
A

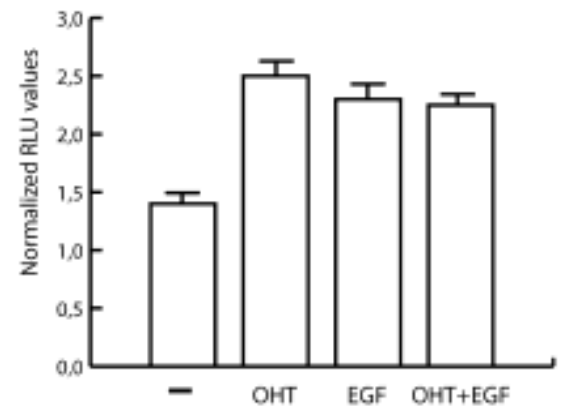

B

mRNA

E-cad

36B4

- OHT EgF OHT+EGF

C

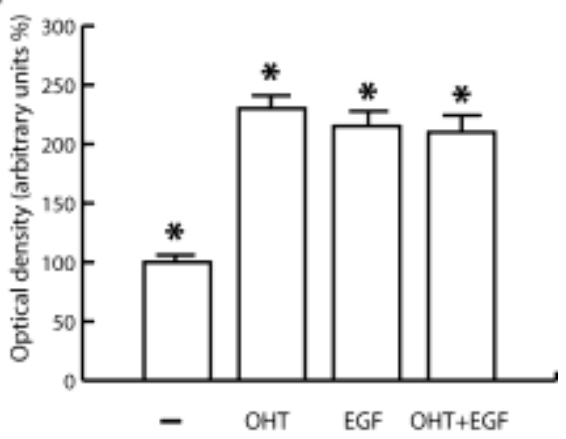


A

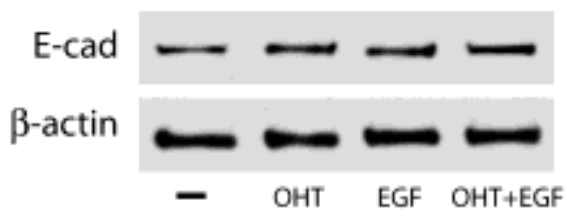

B

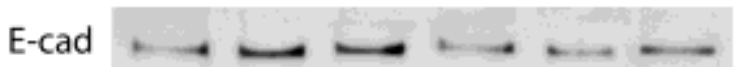
$\beta$-actin

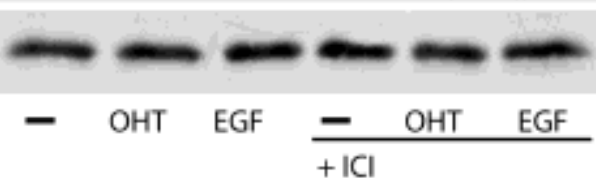

C

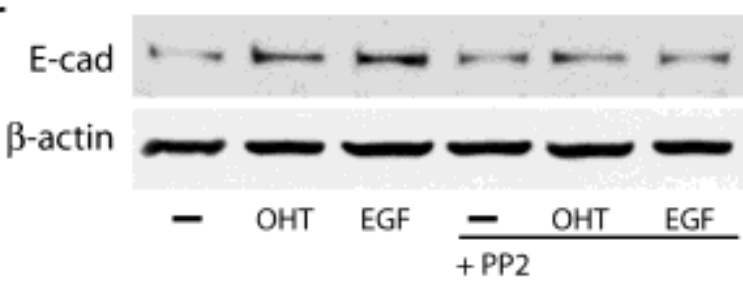

D

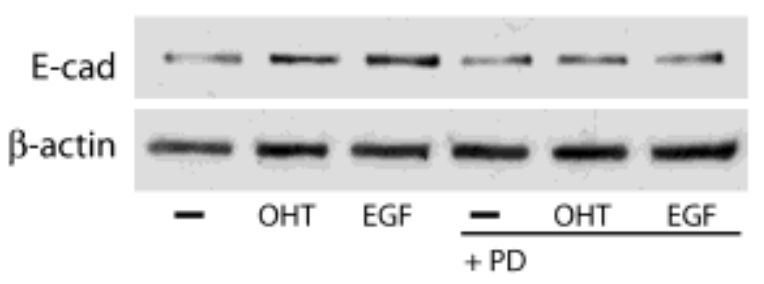

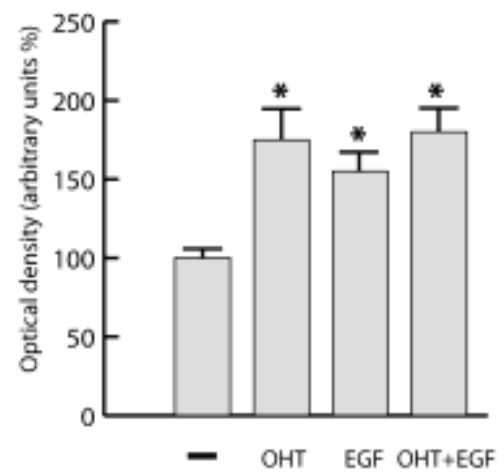
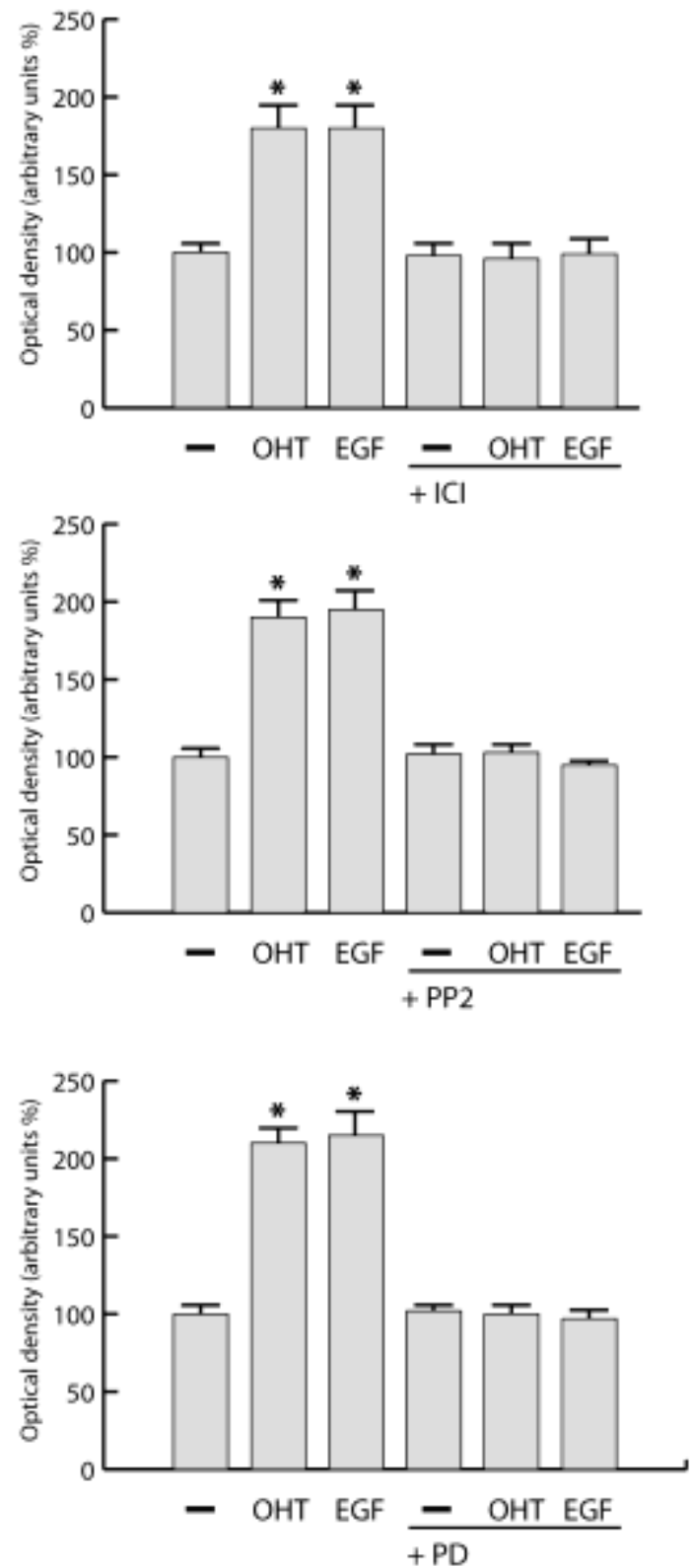
A

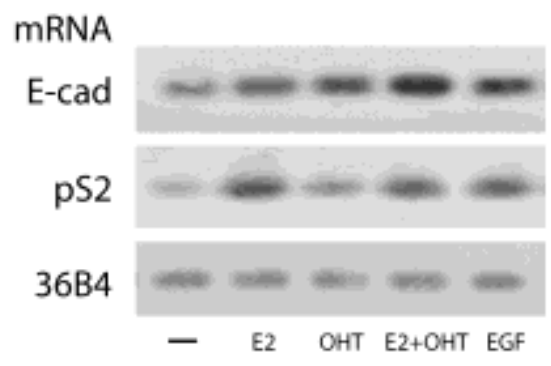

B
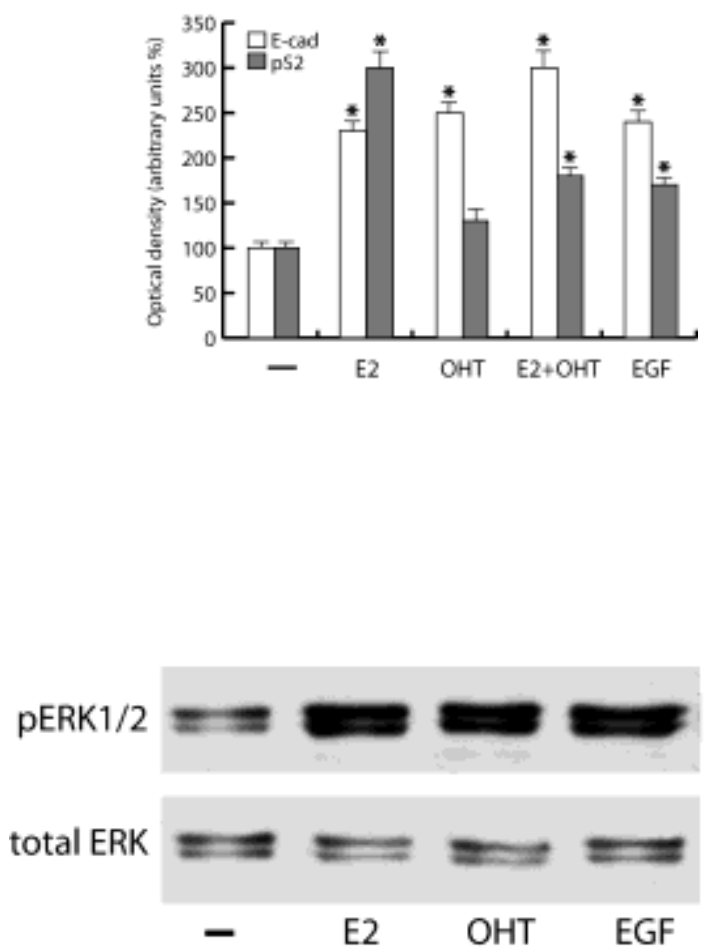

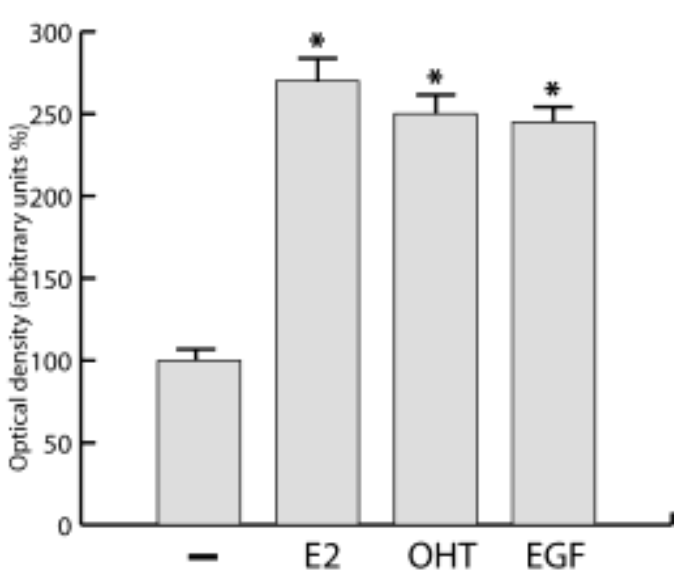


A

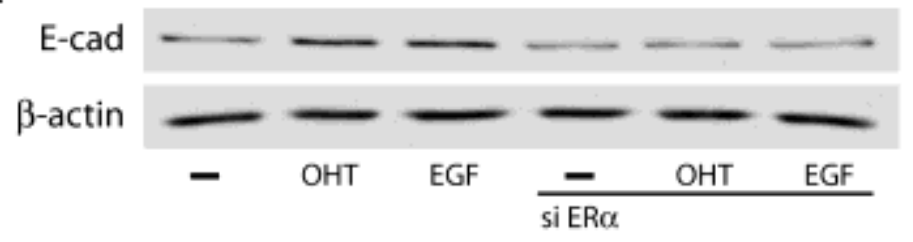

C

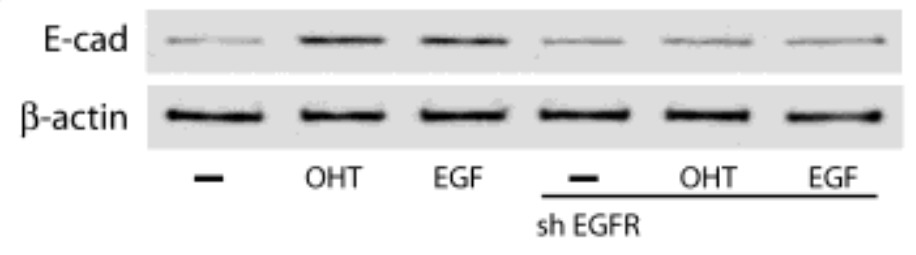

B

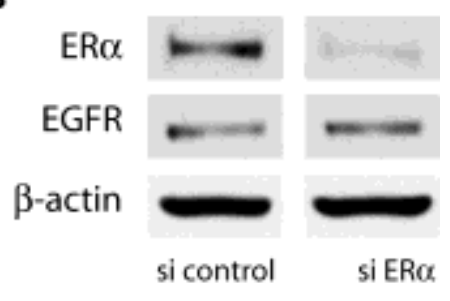

D

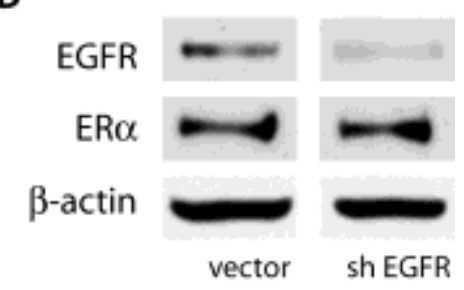

E
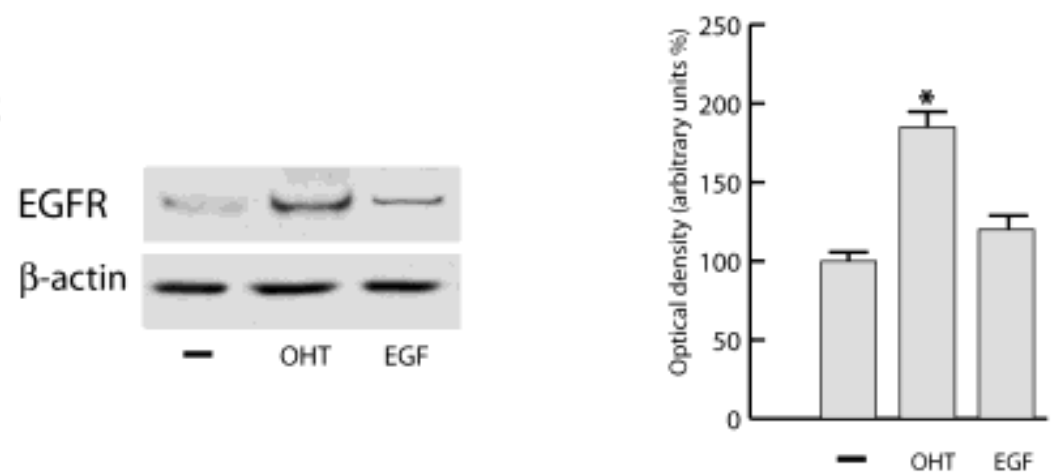
A
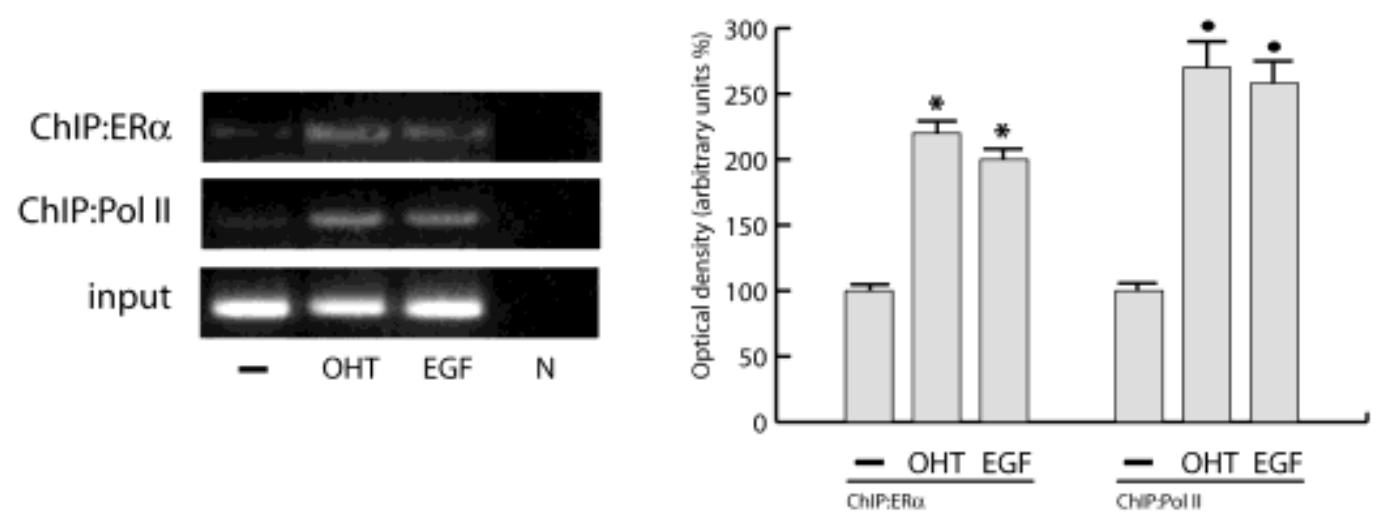

B
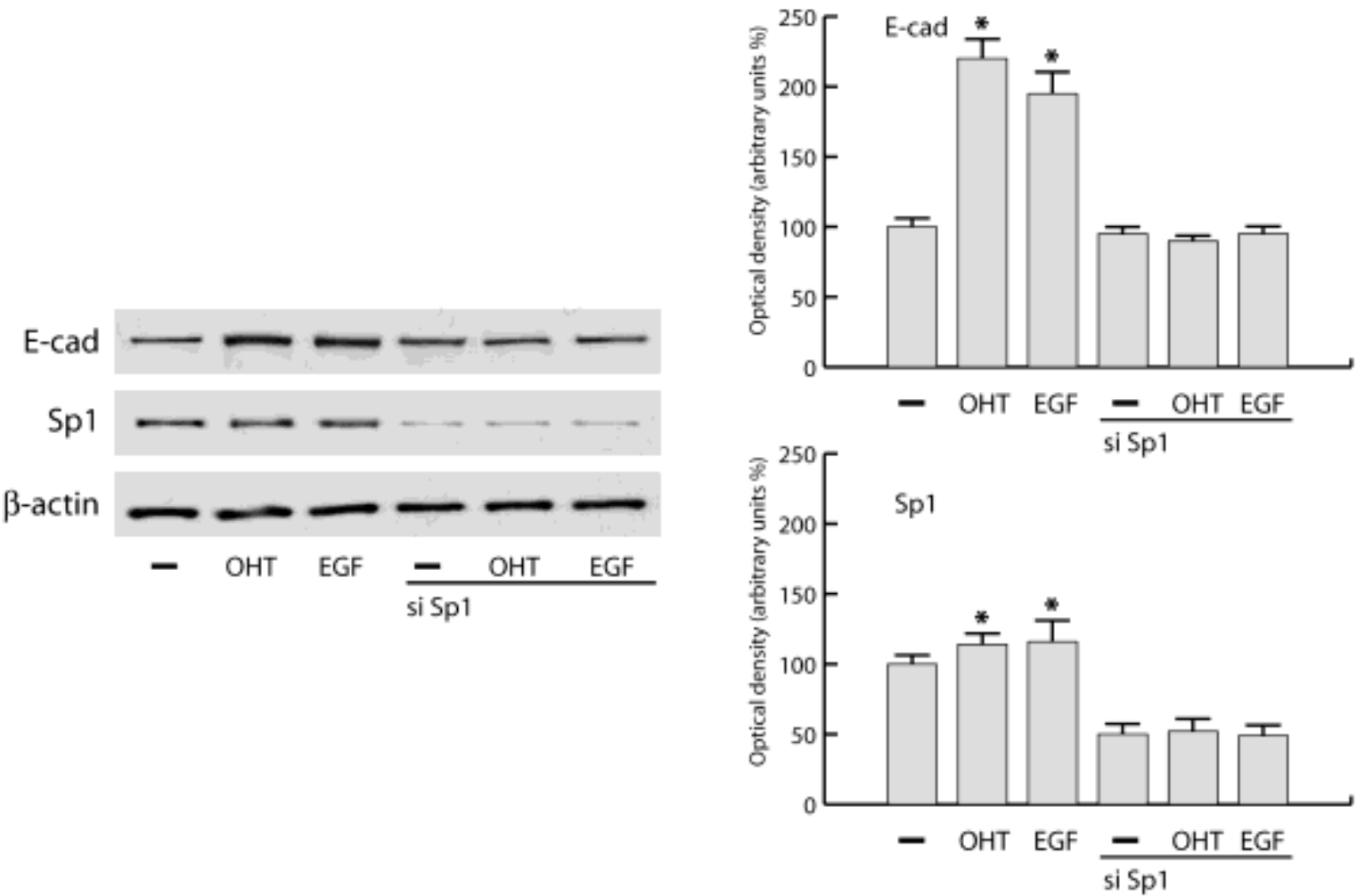

C
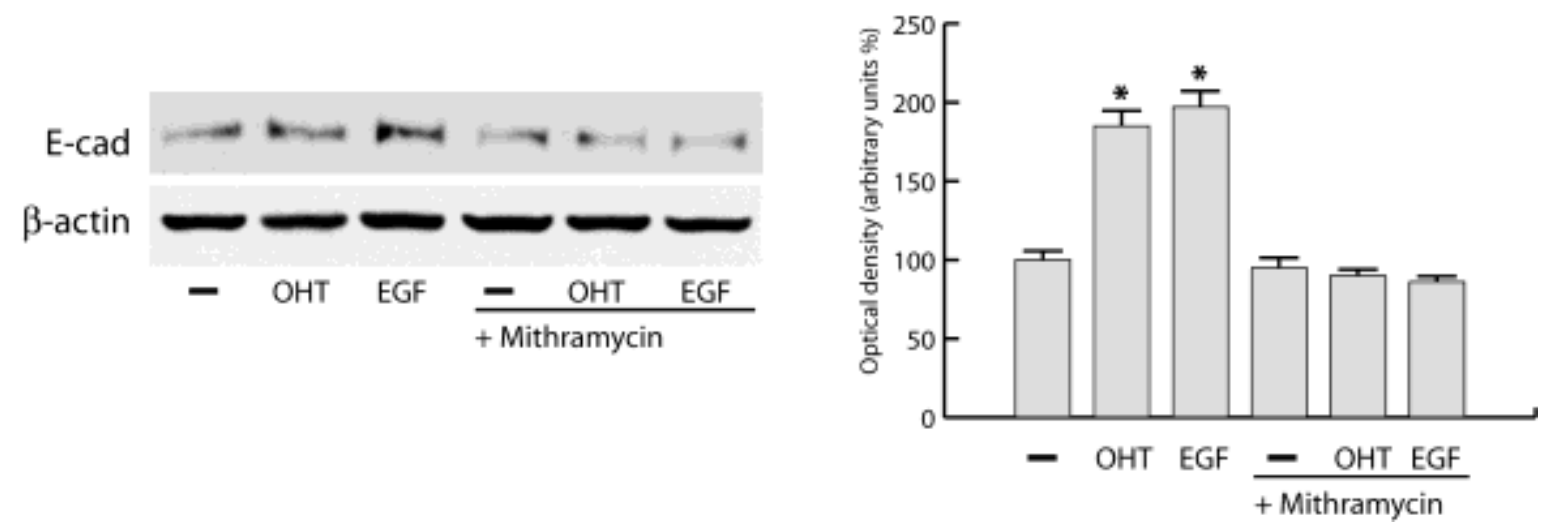


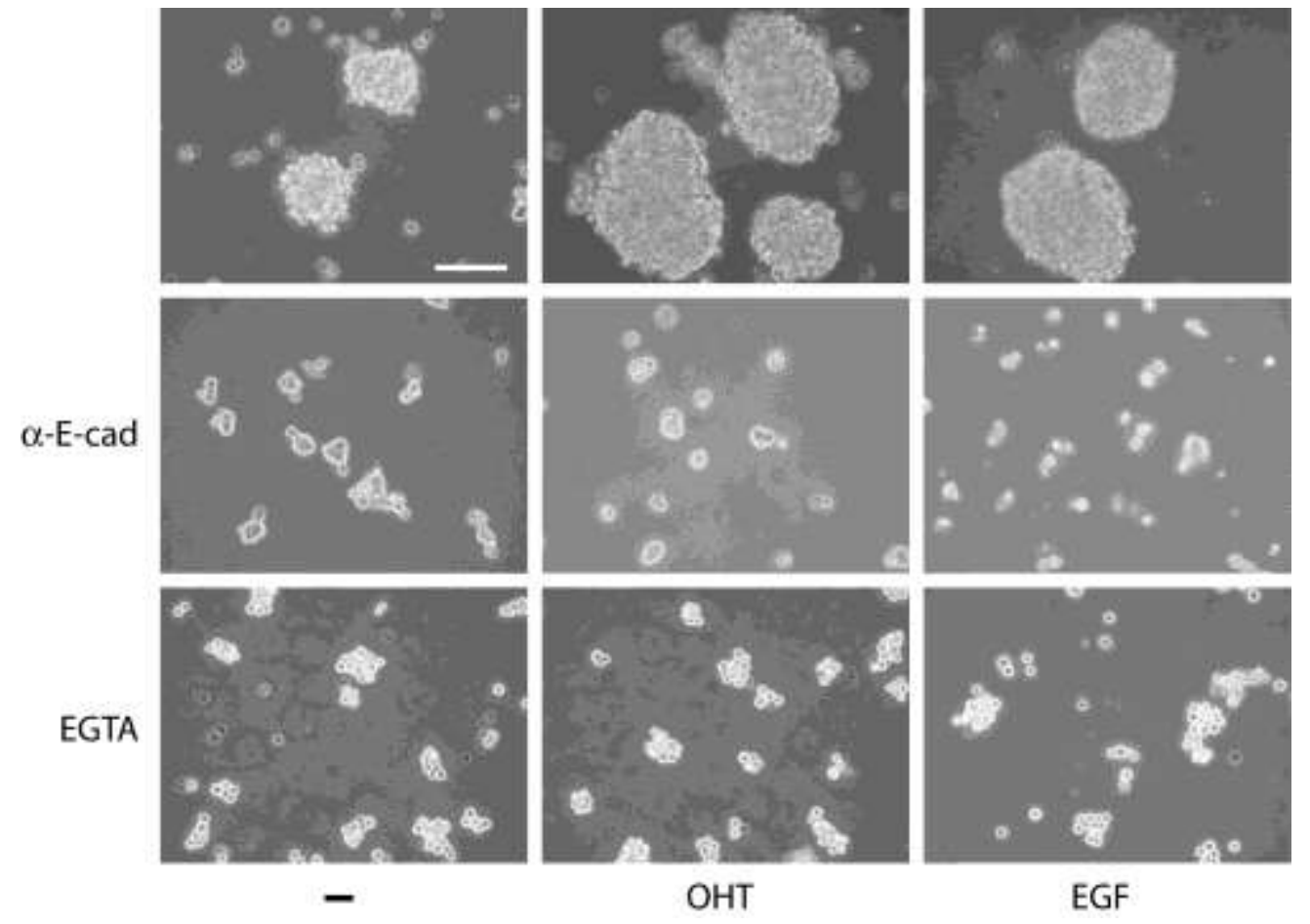


Spheroids

\begin{tabular}{|c|c|c|c|}
\cline { 2 - 4 } \multicolumn{1}{c|}{} & $25 \leq 50 \mu \mathrm{m}$ & $\mathbf{5 0} \leq 100 \mu \mathrm{m}$ & $>100 \mu \mathrm{m}$ \\
\hline Control & $20 \pm 1.3$ & $0.4 \pm 0.1$ & $0.0 \pm 0.0$ \\
\hline OHT & $3 \pm 0.9$ & $15 \pm 1.5$ & $6 \pm 0.8$ \\
\hline EGF & $7 \pm 0.8$ & $21 \pm 1.9$ & $4 \pm 0.6$ \\
\hline
\end{tabular}

